\title{
COVID-19 on an acute psychiatric unit: an interdisciplinary, trauma-informed response
}

\author{
Laura Carroll, Hannah Casey, Rory Adams, Stephanie O'Connor and Áine O'Reilly \\ Department of Psychiatry, Tallaght University Hospital, Dublin, Ireland
}

\begin{abstract}
Purpose - There is a high prevalence of trauma among mental health clients, with risk of re-traumatisation when admitted to a Department of Psychiatry (DoP) (Kimberg and Wheeler, 2019). The COVID-19 pandemic poses challenges to therapy service operations in DoPs, with infection control measures impacting opportunities for therapeutic and social engagement. A trauma-informed care (TIC) lens was used when adapting services in Tallaght University Hospital DoP in response to COVID-19.

Design/methodology/approach - An interdisciplinary approach was taken to adapt therapy services during early stages of the pandemic. Changes were informed by TIC principles to minimise re-traumatisation while maintaining high-quality services. Changes included expansion of the therapeutic activity programme, changes to groups, addition of COVID-19-specific groups and increased awareness of communication support needs.

Findings - The early response to the pandemic, combined with the focus on TIC, resulted in continued, effective therapy services and positive client feedback. With clients' involvement in their care enhanced, Individual Care Planning goals were achieved through group interventions.

Originality/value - The COVID-19 pandemic brought unprecedented changes to mental health services. This paper highlights a response to unique challenges brought by COVID-19 on a DoP.
\end{abstract}

Keywords Trauma-informed care, COVID-19, Acute psychiatry, Therapeutic activity programme (TAP), Interdisciplinary team (IDT), Multidisciplinary team

Paper type Case study

\section{Introduction}

Public health measures implemented by Irish Government in response to COVID-19 impacted mental health service delivery. The DoP in Tallaght University Hospital adopted measures to protect clients and staff.

Measures implemented to minimise risk of virus outbreak included isolation of new admissions, ceased visiting and leave off the unit, physical distancing, bed closures and staff wearing Personal Protective Equipment (PPE). These changes severely impacted clients' opportunities for therapeutic and social engagement. For many clients, the world they were being discharged to was different from pre-admission. Additionally, as time progressed, some admissions appeared directly related to the impact of COVID-19.

Evidence indicates programmes that focus on therapeutic occupational engagement support client's well-being (Hutcheson et al., 2010). The therapeutic activity programme (TAP) in the DoP draws on specialities of music therapy, speech and language therapy and occupational therapy to meet client needs and fulfils obligations for recreational and therapeutic activity stated in Regulations 9 and 16 of the

The current issue and full text archive of this journal is available on Emerald Insight at: https://www.emerald.com/insight/2398-8819.htm

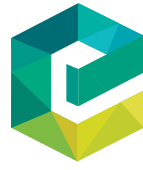

Irish Journal of Occupational Therapy

50/1 (2022) 10-15

Emerald Publishing Limited [ISSN 2398-8819]

[DOI 10.1108/IJOT-04-2021-0011]
Mental Health Commission's Judgement Support Framework (Mental Health Commission, 2020).

Delivery of therapeutic services was adapted to operate within public health guidance. Principles of TIC were used to inform service adaptation. The interdisciplinary team (IDT)previously incorporated TIC in response to trauma histories and traumatising effects of admission. TIC is additionally relevant during this time as the pandemic is globally traumatising (Macpherson, 2020) and necessary public health measures were potentially additionally traumatising.

This article will outline changes to therapy services and how principles of TIC were integrated.

(C) Laura Carroll, Hannah Casey, Rory Adams, Stephanie O'Connor and Áine O'Reilly. Published in Irish fournal of Occupational Therapy. Published by Emerald Publishing Limited. This article is published under the Creative Commons Attribution (CC BY 4.0) licence. Anyone may reproduce, distribute, translate and create derivative works of this article (for both commercial and non-commercial purposes), subject to full attribution to the original publication and authors. The full terms of this licence maybe seen at http://creativecommons.org/licences/by/4.0/legalcode

The authors would like to acknowledge the support received from staff and management in the Department of Psychiatry.

Conflict of interest: The authors declare no conflict of interest.

Received 6 April 2021

Revised 8 September 2021

23 November 2021

28 January 2022

31 January 2022

Accepted 31 January 2022 


\section{Literature review}

\section{Trauma-informed care}

Trauma is a response to overwhelming stress from single or prolonged exposure to events, where individuals experience real or perceived threat of harm to themselves or others (Kezelman and Stavropoulos, 2012).

\section{Therapeutic services in the department of psychiatry}

The Substance Abuse and Mental Health Services Administration (SAMHSA) (2014) highlights increased prevalence of trauma for individuals in mental health services. This, alongside the re-traumatising nature of admission (Kimberg and Wheeler, 2019), requires careful consideration and TIC to support well-being. As many clients on the DoP have experienced significant trauma, TIC is considered essential practice by the IDT. Mounting evidence that DoPs can be re-traumatising led the team to apply "universal trauma precautions", which align well with guiding principles of music therapy, speech and language therapy and occupational therapy (Walsh and Boyle, 2009; Muskett, 2013; Elliott et al., 2005). Irish mental health policy also asserts that services in Ireland should utilise TIC (Department of Health, 2020).

Representative bodies of professions maintain that occupational therapy, music therapy and speech and language therapy are well positioned to apply values relevant to TIC. Core elements include safety, trustworthiness/transparency, peer-support and mutual self-help, collaboration and mutuality, empowerment, choice and voice, sensitivity to cultural, historical and gender issues (Champagne, 2020).

Occupational therapy works from a holistic, nonpathological view of clients and emphasises respect and collaboration, therefore fitting well in TIC. Occupational therapists also focus on the therapeutic relationship, which is a key element in TIC and can be impacted by TIC principles (Fette et al., 2019). Speech and language therapy supports other professions in transparent communication and empowers clients' voices by supporting communication. Bruscia suggests that music therapy, ideally situated within TIC (Porges and Rosetti, 2018), uses musical experiences and relationships developed through them to facilitate positive change (Wigram et al, 2002) including increased emotional and psychological well-being.

\section{COVID-19: the need for trauma-informed care}

Changes required during the pandemic had a triggering impact for many, particularly individuals with pre-existing trauma. Public health measures, uncertainty, lack of control and stress, alongside increased likelihood of violence and mistreatment at home, often resulted in trauma responses (Macpherson, 2020).

The pandemic also resulted in differences in implementation of TIC. When working with individuals who experience trauma, there is emphasis on therapeutic use of self to establish rapport and build alliance (Champagne, 2020). Therapists' non-verbal communications such as facial expression and use of proximity are significant in developing therapeutic processes and relational security. Mask-wearing and social distancing curtailed these therapeutic tools.
TIC was integrated by the IDT to maximise therapeutic use of self and navigate trauma, caused by the pandemic and the DoP's subsequent response.

\section{Methodology}

Pre-pandemic department of psychiatry service

Before COVID-19, open therapeutic groups and individual therapy sessions were available Monday to Friday in the DoP to up to 56 patients. Group sessions included up to 12 members and were open to participants from all wards. Individual therapy with occupational therapy, speech and language therapy and music therapy was available by referral.

Occupational therapy ran multiple groups including selfcare, cookery and art. External facilitators coordinated by occupational therapists included music therapy, yoga and dog therapy. Pre-pandemic music therapy groups included instrumental improvisation, song singing/exploration, lyric composition and circle drumming. Speech and language therapy was available by referral only, focussing mainly on dysphagia assessment.

Department of psychiatry service during the pandemic From March 2020, changes were made to delivery of therapeutic services in the DoP, including changes in the TAP and individual services.

Admissions were significantly curtailed, with approximately $50 \%$ occupancy during the early pandemic period. This resulted in increased facilitation of Individual Care Planning (ICP) goals through group work, and less need for individual input.

Changes made can be seen in Table 1.

\section{Pandemic-specific groups}

Keeping Well at Home with COVID-19 was a dischargeplanning tool supporting well-being during restrictions. The group focussed on routine, relationships and daily activity during lockdown, while providing information on government guidelines. Content drew on Compassion-focussed therapy and aimed to acknowledge feelings of active traumatisation (Gilbert, 2009).Group discussion and brainstorming was utilised to plan for self-isolation on discharge while accessing social supports, alongside tips on managing mental health during lockdown.

During the pandemic, misinformation was common and individuals in the DoP had limited access to reliable information about COVID-19. Alongside this, some clients were unsure as to reasoning for restrictions as information provided did not meet their communication needs. This highlighted the need for speech and language therapy input to a COVID-19 Information Session to support individuals accessing reliable information as per their communication support needs. This was co-designed and delivered by occupational therapists, using their expertise in group facilitation.

Music therapy consisted of song-singing and music-listening groups only. Extra ad-hoc ward-based sing-alongs were introduced providing opportunities to experience music 
Table 1 Changes made

\begin{tabular}{|c|c|c|c|}
\hline Pre-Pandemic TAP & Changes Made & Rationale & Principle of TIC \\
\hline $\begin{array}{l}\text { Discharge planning } \\
\text { groups informed by } \\
\text { WRAP, no COVID- } \\
\text { Specific information }\end{array}$ & $\begin{array}{l}\text { Design of "Keeping Well at Home } \\
\text { with COVID-19" group to specifically } \\
\text { plan for discharge to quarantine - } \\
\text { discussion based group focusing on } \\
\text { planning for discharge home }\end{array}$ & $\begin{array}{l}\text { Enable Clients to access peer } \\
\text { support, validate feelings and social } \\
\text { connections when planning for } \\
\text { discharge home. Inform Clients of } \\
\text { difficulties outside of hospital }\end{array}$ & Peer support and mutuality \\
\hline $\begin{array}{l}\text { Focus on functional } \\
\text { tasks, some focus on } \\
\text { social interactions, } \\
\text { visitors allowed onto } \\
\text { the unit e.g. cooking } \\
\text { group }\end{array}$ & $\begin{array}{l}\text { Increase in groups based on social } \\
\text { interactions and client collaboration } \\
\text { e.g. Tea and Newspapers, Music } \\
\text { Therapy, Art \& Craft }\end{array}$ & $\begin{array}{l}\text { Enable Clients to access peer support } \\
\text { and encourage mutual self-help. } \\
\text { Support individuals to forge } \\
\text { meaningful social connections in the } \\
\text { absence of pre-existing social } \\
\text { supports outside the hospital }\end{array}$ & Peer support and mutuality \\
\hline $\begin{array}{l}\text { Groups scheduled as } \\
\text { per caseload demands } \\
\text { of staff }\end{array}$ & $\begin{array}{l}\text { Groups scheduled at regular times } \\
\text { daily e.g. Art \& Craft at } 2 \mathrm{pm} \text {, } \\
\text { Morning and Evening Stretching at } \\
\text { 9.30am and } 6.30 \mathrm{pm} . \text {, with small } \\
\text { changes as per client requests }\end{array}$ & $\begin{array}{l}\text { Support structure and routine } \\
\text { offering containment and } \\
\text { predictability to Clients on the unit. } \\
\text { Minimise uncertainty or change }\end{array}$ & Predictability and Structure \\
\hline $\begin{array}{l}\text { Decisions made in } \\
\text { consultation with ward } \\
\text { staff and using clinician } \\
\text { judgment }\end{array}$ & $\begin{array}{l}\text { Decisions for most groups made by } \\
\text { means of a voting system by Clients } \\
\text { e.g. show to watch during Netflix } \\
\text { Group, Newspapers purchased for Tea } \\
\text { and Newspaper groups }\end{array}$ & $\begin{array}{l}\text { Offer agency and control over group } \\
\text { details to Clients. Support diplomatic } \\
\text { and transparent decision making }\end{array}$ & $\begin{array}{l}\text { Supporting individuals to have } \\
\text { agency, choice and control; } \\
\text { Trustworthiness and transparency; } \\
\text { Collaboration and mutuality }\end{array}$ \\
\hline $\begin{array}{l}\text { Choices offered during } \\
\text { groups but not } \\
\text { maximised. Some more } \\
\text { directive group content }\end{array}$ & $\begin{array}{l}\text { Choices offered within groups as } \\
\text { much as possible by offering a } \\
\text { selection of materials e.g. } \\
\text { newspapers, songs, or art projects }\end{array}$ & $\begin{array}{l}\text { Support individuals to exert agency } \\
\text { and control over their participation in } \\
\text { the group }\end{array}$ & $\begin{array}{l}\text { Supporting individuals to have } \\
\text { agency, choice and control }\end{array}$ \\
\hline $\begin{array}{l}\text { 2-3 groups per day, } \\
\text { depending on caseload } \\
\text { demands of staff }\end{array}$ & $\begin{array}{l}\text { Increased number and selection of } \\
\text { groups. } 7 \text { groups available Monday- } \\
\text { Friday, } 5 \text { available on Saturdays }\end{array}$ & $\begin{array}{l}\text { Enabling Clients to have choice over } \\
\text { what groups they did/did not attend. } \\
\text { Supporting choice over routine } \\
\text { within the ward structure }\end{array}$ & $\begin{array}{l}\text { Supporting individuals to have } \\
\text { agency, choice and control }\end{array}$ \\
\hline $\begin{array}{l}\text { Cultural and spiritual } \\
\text { needs met outside the } \\
\text { TAP e.g. attended } \\
\text { religious service in } \\
\text { hospital chapel }\end{array}$ & $\begin{array}{l}\text { Inclusion of culturally relevant } \\
\text { activities in group design e.g. Tea } \\
\text { and Newspaper, Mass }\end{array}$ & $\begin{array}{l}\text { Support Clients to engage in } \\
\text { meaningful and culturally relevant } \\
\text { occupations }\end{array}$ & $\begin{array}{l}\text { Cultural, gender and historical } \\
\text { responsivity }\end{array}$ \\
\hline $\begin{array}{l}\text { Increased focus on } \\
\text { physical body-focused } \\
\text { trauma processing } \\
\text { utilised in individual } \\
\text { sessions }\end{array}$ & $\begin{array}{l}\text { Further inclusion of physical body- } \\
\text { focused trauma processing in } \\
\text { group sessions e.g. gentle stretching, } \\
\text { yoga, relaxation. Inclusion of body } \\
\text { focused measures, such as mindful } \\
\text { breathing in MT }\end{array}$ & $\begin{array}{l}\text { To assist people in achieving a safe } \\
\text { and social ventral vagal state and to } \\
\text { regain a feeling of safety inside their } \\
\text { bodies (Van der Kolk, 2014) }\end{array}$ & $\begin{array}{l}\text { Provide the opportunity for people } \\
\text { to } \\
\text { 1. learn to recognise } \\
\text { 2. tolerate } \\
\text { 3. regulate } \\
\text { their physical responses to trauma }\end{array}$ \\
\hline $\begin{array}{l}\text { Timetables available } \\
\text { from staff, printed and } \\
\text { displayed on Monday } \\
\text { mornings }\end{array}$ & $\begin{array}{l}\text { Timetables printed in advance and } \\
\text { clearly displayed around the wards, } \\
\text { days in advance where possible }\end{array}$ & $\begin{array}{l}\text { Enable clear communication between } \\
\text { staff and Clients, enable transparency } \\
\text { and the opportunity for Clients to plan } \\
\text { and structure their day }\end{array}$ & $\begin{array}{l}\text { Transparency and trustworthiness; } \\
\text { Structure, routine and } \\
\text { predictability }\end{array}$ \\
\hline $\begin{array}{l}\text { One version of } \\
\text { the timetable available } \\
\text { for all Clients }\end{array}$ & $\begin{array}{l}\text { Efforts made to make timetables } \\
\text { accessible for all e.g. translated into } \\
\text { Spanish, image for each group, print } \\
\text { in larger font, additional timetables }\end{array}$ & $\begin{array}{l}\text { Enable Clients to access information } \\
\text { on the groups, regardless of } \\
\text { language barriers, literacy levels or } \\
\text { visual needs }\end{array}$ & $\begin{array}{l}\text { Cultural, gender and historical } \\
\text { responsivity; Supporting } \\
\text { individuals to have agency, choice } \\
\text { and control }\end{array}$ \\
\hline
\end{tabular}

printed for individual use and

verbally informed when each group

was due to start 
Table 1

\begin{tabular}{|c|c|c|c|}
\hline Pre-Pandemic TAP & Changes Made & Rationale & Principle of TIC \\
\hline $\begin{array}{l}\text { Groups designed in } \\
\text { accordance with staff } \\
\text { capacity and feedback } \\
\text { from ward "community } \\
\text { meetings" }\end{array}$ & $\begin{array}{l}\text { Clients were encouraged on ward to } \\
\text { ask about and input into the } \\
\text { planning process for groups }\end{array}$ & $\begin{array}{l}\text { Support Clients to collaborate with } \\
\text { staff to ensure therapeutic services } \\
\text { meeting needs. Ensuring a wide } \\
\text { variety of occupations were } \\
\text { supported in lieu of activity }\end{array}$ & $\begin{array}{l}\text { Transparency and trustworthiness; } \\
\text { Collaboration and mutuality }\end{array}$ \\
\hline $\begin{array}{l}\text { Group development } \\
\text { undertaken by staff } \\
\text { only }\end{array}$ & $\begin{array}{l}\text { Projects undertaken with staff and } \\
\text { Clients e.g. resource provision for } \\
\text { wards co-designed with Clients }\end{array}$ & $\begin{array}{l}\text { Support Clients to exert agency and } \\
\text { control over the resources available, } \\
\text { ensure collaborative practice }\end{array}$ & $\begin{array}{l}\text { Supporting individuals to have } \\
\text { agency, choice and control; } \\
\text { Collaboration and mutuality }\end{array}$ \\
\hline $\begin{array}{l}\text { Evaluation on an } \\
\text { informal basis e.g. } \\
\text { informal verbal } \\
\text { feedback }\end{array}$ & $\begin{array}{l}\text { Structured evaluations completed } \\
\text { within music therapy groups e.g. } \\
\text { written feedback forms }\end{array}$ & $\begin{array}{l}\text { To encourage collaboration and } \\
\text { incorporate client feedback }\end{array}$ & $\begin{array}{l}\text { Supporting individuals to have } \\
\text { agency, and to be heard }\end{array}$ \\
\hline $\begin{array}{l}\text { Music therapy only } \\
\text { available in scheduled } \\
\text { group sessions and by } \\
\text { referral }\end{array}$ & $\begin{array}{l}\text { Addition of "ad-hoc" music therapy } \\
\text { sessions on the ward }\end{array}$ & $\begin{array}{l}\text { To provide distraction from } \\
\text { confinement to the unit. To develop } \\
\text { communication and trust between } \\
\text { staff and Clients and to enable social } \\
\text { interaction }\end{array}$ & $\begin{array}{l}\text { Safe engagement, trust, social } \\
\text { connectedness, valuing individual } \\
\text { contributions in a group context }\end{array}$ \\
\hline $\begin{array}{l}\text { Speech and Language } \\
\text { Therapy mainly referred } \\
\text { to for swallowing } \\
\text { difficulties }\end{array}$ & $\begin{array}{l}\text { Increased referral to Speech and } \\
\text { Language Therapy especially for } \\
\text { communication needs }\end{array}$ & $\begin{array}{l}\text { Heightened awareness of the impact } \\
\text { of communication support needs }\end{array}$ & $\begin{array}{l}\text { Supporting individuals to have } \\
\text { agency, choice, control and to be } \\
\text { heard }\end{array}$ \\
\hline $\begin{array}{l}\text { Occupational therapy- } \\
\text { led groups included; } \\
\text { cookery, self-care, } \\
\text { WRAP, } \\
\text { relaxation, stretching }\end{array}$ & $\begin{array}{l}\text { Cookery and self-care groups } \\
\text { discontinued due to infection control } \\
\text { restrictions. Additional groups } \\
\text { introduced, including table tennis, } \\
\text { art, gardening, exercise videos, } \\
\text { scrapbooking, streamed mass }\end{array}$ & $\begin{array}{l}\text { To provide opportunities for } \\
\text { individuals to engage in safe, } \\
\text { meaningful occupation despite } \\
\text { restrictions. To offer enhanced choice } \\
\text { and opportunity to Clients }\end{array}$ & $\begin{array}{l}\text { Supporting individuals to have } \\
\text { agency, choice and control }\end{array}$ \\
\hline $\begin{array}{l}\text { External facilitators to } \\
\text { facilitate groups } \\
\text { (including yoga, } \\
\text { exercise, dog therapy) }\end{array}$ & $\begin{array}{l}\text { External facilitators cancelled - yoga } \\
\text { reintroduced virtually with a trauma- } \\
\text { informed yoga instructor }\end{array}$ & $\begin{array}{l}\text { To provide opportunities for } \\
\text { engagement with valued activities } \\
\text { and important body-focused activity }\end{array}$ & $\begin{array}{l}\text { Safe engagement, safety within } \\
\text { the body, Provide the opportunity } \\
\text { for people to } \\
\text { 1. learn to recognise } \\
\text { 2. tolerate } \\
\text { 3. regulate their physical responses } \\
\text { to trauma }\end{array}$ \\
\hline $\begin{array}{l}\text { Up to } 12 \text { participants } \\
\text { in an open group, no } \\
\text { social distancing, no } \\
\text { PPE or sterilisation } \\
\text { procedures }\end{array}$ & $\begin{array}{l}\text { Limited participants to } 5 \text { in an } \\
\text { open group, increased social } \\
\text { distancing and PPE requirements. } \\
\text { Increased group numbers to } \\
\text { accommodate all Clients }\end{array}$ & $\begin{array}{l}\text { Provide opportunities for safe } \\
\text { engagement }\end{array}$ & Safe engagement with activity \\
\hline $\begin{array}{l}\text { Most group sessions } \\
\text { happening once weekly } \\
\text { to meet client needs }\end{array}$ & $\begin{array}{l}\text { Some group sessions increased to } \\
\text { daily to facilitate increased client } \\
\text { needs and decreased attendance, } \\
\text { and in line with client feedback. E.g. } \\
\text { Art \& Craft, Wake Up \& Stretch }\end{array}$ & $\begin{array}{l}\text { Provide opportunities for safe } \\
\text { engagement, ensure a wide range of } \\
\text { opportunities for each client }\end{array}$ & $\begin{array}{l}\text { Supporting individuals to have } \\
\text { agency, choice and control }\end{array}$ \\
\hline $\begin{array}{l}\text { ICP Goals met using } \\
\text { individual therapies } \\
\text { and through the TAP }\end{array}$ & $\begin{array}{l}\text { TAP tailored to ICP needs in } \\
\text { collaboration with Clients - made } \\
\text { possible by reduced numbers on the } \\
\text { unit }\end{array}$ & $\begin{array}{l}\text { To provide increased opportunities } \\
\text { for engagement, enhanced ability to } \\
\text { meet ICP needs }\end{array}$ & $\begin{array}{l}\text { Supporting individuals to have } \\
\text { agency, choice and control. } \\
\text { Collaboration and mutuality }\end{array}$ \\
\hline $\begin{array}{l}\text { Groups ran Monday to } \\
\text { Friday, between } 8 \mathrm{am} \\
\text { and } 4 \mathrm{pm} \text {. Both } \\
\text { occupational therapists } \\
\text { working alongside each } \\
\text { other }\end{array}$ & $\begin{array}{l}\text { Group programme extended to run } \\
\text { from } 8 \text { am to } 8 \text { pm, Monday to Friday } \\
\text { and } 8 \mathrm{am} \text { - } 7 \mathrm{pm} \text { on Saturday. } \\
\text { Occupational therapists working } \\
\text { opposite days to minimise contact }\end{array}$ & $\begin{array}{l}\text { To provide increased opportunities } \\
\text { for engagement, and offer safe space } \\
\text { away from the uncertainty of COVID }\end{array}$ & $\begin{array}{l}\text { Supporting individuals to have } \\
\text { agency, choice and control, safe } \\
\text { engagement in activity }\end{array}$ \\
\hline
\end{tabular}


therapy without attending structured groups where this felt difficult.

Initial adaptations continued until June 2020, at which time, increasing admissions and reduced national restrictions warranted a service review. The service adapted to meet changing demands, preserving effective elements, including infection control precautions and increased choice in groups.

\section{Discussion}

\section{Outcomes of adapted services}

As a result of integration of TIC into the service, a number of outcomes were achieved:

- continuation of therapy service and TAP;

- increased awareness of communication support needs leading to increased speech and language therapy presence;

- more ICP goals achieved through group intervention;

- positive feedback from clients;

- effective, sustainable aspects of the adapted service preserved;

- increased emphasis on body-based trauma-processing; and

- enhanced focus on clients' involvement in their care.

To ensure service effectiveness, feedback was elicited using a number of measures, including group attendance and verbal feedback. This encompassed principles of transparency and collaboration, ensuring a trauma-informed environment was established and therapeutic relationships incorporated trust. An evaluation of music therapy found sessions supported decreased feelings of isolation and improved coping.

Occupational therapy evaluation was carried out through the yearly audit, alongside evaluation of the TAP as a whole, which demonstrated a $240 \%$ increase in the number of groups. The amount of time spent in group therapies increased by $10 \%$ from June 2019 to June 2020, despite significantly reduced numbers on the ward, demonstrating increased time spent engaged in meaningful occupation. Many clients attended most groups, reporting this supported them achieving ICP goals such improved routine, socialising and practicing coping techniques learned on the unit, which were key occupational therapy outcomes.

The TAP provided opportunities for social connection and peer-support when these were restricted. Face-to-face contact allowed continued therapeutic use of self, providing safe, social cues and reducing dysregulation. This fostered a sense of safety in groups, an important foundation of TIC (Champagne, 2020). With facial expressions and proximity restricted by mask-wearing, additional emphasis was placed on alternative methods of non-verbal and paralinguistic communication, including written communication.

Speech and language therapy services were further developed in two ways. Additional resources were allocated to address barriers to communication which exist in services which fail to take communication support needs into account, for example through staff training, review of communication accessibility of ICP processes and interventions. Extra resources were provided to assess, provide intervention and advise on communication support needs of individual clients.
The Mental Health Commission mandates ICPs in Approved Centres in Ireland to support clients communicating needs and planning to meet these in collaboration with their team. Given the smaller cohort in the DoP, these goals could effectively be met through group activity, requiring less individual work.

\section{Limitations of the adapted service}

Service adaptation took place during early stages of the pandemic and, as such, was a reactive response to an emergency. Therefore there were limitations to its scope and effectiveness.

While the adapted service effectively met client needs, it required occupational therapists to work alone. The intensive input was unsustainable and at the point of service reduction in June, both occupational therapists were experiencing burnout.

As the number of admissions increased, it became increasingly challenging to meet ICP goals through group activity given increased variety in goals and number of clients, requiring reallocation of resources from group therapy to individual work. The TAP continued to operate in a slightly reduced capacity, with increased individual referrals to all disciplines. Meeting increasingly varying goals through activity was challenging given constraints of social distancing and IPC, requiring individual referrals.

The adapted service supported social interactions and connectedness, however, given restrictions on socialisation, clients continued to be isolated from support networks.

\section{Implications for future practice}

Integration of TIC into therapeutic services in the DoP during the pandemic had positive outcomes despite limitations. This supports further integration across the DoP.

It is vital to acknowledge the role of interdisciplinary working in service delivery. Incorporating guidance from all disciplines supported consistency across therapeutic services. Close collaboration ensured cohesive integration of TIC, ensuring equity and consistency for clients. Regular IDT engagement and on-site working enabled effective implementation.

Music therapy's structured service evaluation provided insights into clients' perceptions. Further structured evaluation should be regularly undertaken to capture client's perceptions and enhance the collaborative nature of the service.

\section{Conclusion}

A need was identified at the beginning of the pandemic to adapt therapies services in the DoP. A trauma-informed, interdisciplinary suite of changes was made to services. Adaptations made to therapeutic services supported clients to safely engage with therapies during the pandemic. Adapting and offering enhanced services was challenging but necessary. Effective changes made included:

- changes to group structure and content;

- enhanced emphasis on body-oriented trauma-processing and embodied trauma;

- increased awareness of communication support needs;

- greater focus on supporting clients' involvement in their care;

- increased emphasis on social connections; 
- additional speech and language therapy and music therapy resources; and

- continued development of practice into a traumainformed therapy service.

Limitations included difficulty with sustainability, burnout and continued restrictions. This brief description offers reflections on integration of principles of TIC into therapeutic services in a DoP during the COVID-19 pandemic. This was an effective response and continues to inform practice.

\section{References}

Champagne, T. (2020), "Trauma-informed care", in Carson, N. (Ed.), Psychosocial Occupational Therapy, 1st ed., Elsevier, Philadelphia, PA, pp. 241-251.

Department of Health (2020), Sharing the Vision: A Mental Health Policy for Everyone, Stationary Office, Dublin.

Elliott, D., Bjelajac, P., Fallot, R., Markoff, L. and GloverReed, B. (2005), "Trauma-informed or trauma-denied: principles and implementation of trauma-informed services for women", fournal of Community Psychology, Vol. 33 No. 4, pp. 461-477.

Fette, C., Lambdin-Pattavina, C. and Weaver, L. (2019), Understanding and Applying Trauma-Informed Approaches across Occupational Therapy Settings, AOTA: Bethesda, MD.

Gilbert, P. (2009), "Introducing compassion-focused therapy", Advances in Psychiatric Treatment, Vol. 15 No. 3, pp. 199-208.

Hutcheson, C., Ferguson, H., Nish, G. and Gill, L. (2010), "Promoting mental wellbeing through activity in a mental health hospital", British fournal of Occupational Therapy, Vol. 73 No. 3, pp. 121-128.

Kezelman, C. and Stavropoulos, P. (2012), The Last Frontier: Practice Guidelines for Treatment of Complex Trauma and Trauma-Informed Care and Service Delivery, Adults Surviving Child Abuse, Kirribilli.
Kimberg, L. and Wheeler, M. (2019), "Trauma and traumainformed care", in Kimberg, L. (Ed.), Trauma-Informed Healthcare Approaches; a Guide for Primary Care, 1st ed., Springer, Cham, pp. 25-56.

Macpherson, G. (2020), "Episode 436. Bruce Perry, MD, PhD. Staying emotionally close in the time of COVID-19 [video]", The Trauma Therapist Project, available at: www. thetraumatherapistproject.com/podcast/bruce-perry-md-phdstaying-emotionally-close-in-the-time-of-COVID-19/

Mental Health Commission (2020), Fudgement Support Framework v.5.1, Mental Health Commission, Dublin, p. 4.

Muskett, C. (2013), "Trauma-informed care in inpatient mental health settings: a review of the literature", International fournal of Mental Health Nursing, Vol. 23 No. 1, pp. 53-59.

Porges, S. and Rosetti, A. (2018), "Music, music therapy and trauma", Music and Medicine, Vol. 10 No. 3, pp. 117-120.

Substance Abuse and Mental Health Services Administration (2014), SAMHSA's Concept of Trauma and Guidance for a Trauma-Informed Approach, HHS Publication No.(SMA) 14-4884, SAMSHA, Rockville, MD.

Van der Kolk, B. (2014), The Body Keeps the Score; Mind, Brain and Body in the Transformation of Trauma, Penguin Books, New York, NY.

Walsh, J. and Boyle, J. (2009), "Improving acute psychiatric hospital services according to inpatient experiences. A userled piece of research as a means to empowerment", Issues in Mental Health Nursing, Vol. 30 No. 1, pp. 31-38.

Wigram, T., Pedersen, I.N. and Bonde, L.O. (2002), A Comprehensive Guide to Music Therapy; Theory, Clinical Practice, Research and Training, Jessica Kingsley Publishers, Philadelphia, PA.

\section{Corresponding author}

Laura Carroll can be contacted at: LAURA.CARROLL06@ TUH.IE 